\title{
Letter regarding the article entitled: 'Rapidly progressive sporadic CreutzfeldtJakob disease: isolated Heidenhain variant or a combination with PRES?'
}

\author{
Carta referente ao artigo intitulado: 'Doença de Creutzfeldt-Jakob esporádica \\ rapidamente progressiva: variante Heidenhain isolada ou PRES combinada?'
}

Halil ONDER ${ }^{1}$

\section{Dear Editor,}

I read with interest the article by Fraiman et al. ${ }^{1}$ in which they present a patient who they define as probable Creutzfeldt-Jakob disease (CJD) associated with posterior reversible encephalopathy syndrome (PRES). I would like to make some comments hoping to provide a better understanding of the report.

I believe that there may be some critical question marks regarding the patient's evaluation process and diagnosis. First, I think that data regarding the medical history and the results of the laboratory investigations should be indicated in the report for a clear understanding. The authors associate the CJD with PRES which are clinically and pathophysiologically quite distinct entities. CJD is a neurodegenerative disease characterized by progressive dementia, cerebellar ataxia, myoclonus, together with pyramidal and extrapyramidal signs ${ }^{2}$. However, PRES is an acute-onset disease that is considered to be associated with vascular leakage, vasogenic edema, and endothelial dysfunction ${ }^{3}$. Remarkably, it generally resolves completely spontaneously ${ }^{3}$ and there is no data regarding the role of underlying neurodegeneration in the pathophysiology of PRES. Taken together, to report such an atypical association, the documentation of the patient should be more detailed. For instance, the time of the clinical presentations and their temporal evaluation should be noted separately in detail. The authors state the involvement of visual agnosia in the clinic, it is also important that if the patient suffered from headaches during the onset of clinical presentations, and were the blood pressures elevated at that time? Besides, the follow-up of the patient is very critical in discriminating the pathophysiology responsible from the clinic. The DWI is a critical tool in the diagnosis of CJD and it has high sensitivity and specificity throughout the disease course ${ }^{2}$. At this point, the follow-up DWI showing the persistence of cortical diffusion restriction would provide very important data supporting the underlying CJD in this atypical clinical scenario. The presence of 14-3-3 protein is surely an important finding supporting the diagnosis of CJD; however, we know that it can be present in many other neurological diseases ${ }^{4}$ likewise periodic sharp wave complexes ${ }^{5}$. Otherwise, in the current state of this report ${ }^{1}$, the presence of an underlying CJD may be questionable, as misdiagnosis of CJD has been reported several times previously ${ }^{6}$. For instance, in the absence of abnormal signals in the follow-up MRIs, it can be considered that an underlying PRES may be responsible for the whole clinic and neuroimaging data.

\section{REFERENCES}

1. Fraiman PHA, Teixeira CM, de Oliveira JCD, et al. Rapidly progressive sporadic Creutzfeldt-Jakob disease: isolated Heidenhain variant or a combination with PRES? Arq Neuropsiquiatr. 2021;79(4):352-3. https://doi.org/10.1590/0004-282X-ANP-2020-0428

2. Young GS, Geschwind MD, Fischbein NJ, et al. Diffusion-weighted and fluid-attenuated inversion recovery imaging in Creutzfeldt-Jakob disease: high sensitivity and specificity for diagnosis. AJNR Am J Neuroradiol. 2005;26(6):1551-62.

3. Fugate JE, Rabinstein AA. Posterior reversible encephalopathy syndrome: clinical and radiological manifestations, pathophysiology, and outstanding questions. Lancet Neurol. 2015 Sep;14(9):914-25. https://doi.org/10.1016/s1474-4422(15)00111-8
4. Gronseth GS, Paduga R, American Academy of Neurology. Evidencebased guideline update: steroids and antivirals for Bell palsy: Report of the Guideline Development Subcommittee of the American Academy of Neurology. Neurology. 2012 Nov 27;79(22):2209-13.

5. Savard M, Irani SR, Guillemette A, et al. Creutzfeldt-Jakob DiseaseLike Periodic sharp wave complexes in voltage-gated potassium channel-complex antibodies encephalitis: A case report. J Clin Neurophysiol. 2016 Feb;33(1):e1-4. https://doi.org/10.1097/ wnp.0000000000000171

6. Chitravas N, Jung RS, Kofskey DM, et al. Treatable neurological disorders misdiagnosed as Creutzfeldt-Jakob disease. Ann Neurol. 2011 Sep;70(3):437-44. https://doi.org/10.1002/ana.22454

${ }^{1}$ Yozgat City Hospital, Neurology Clinic, Yozgat, Turkey.

HO (D) https://orcid.org/0000-0002-1823-2278

Correspondence: Halil Onder; Email: halilnder@yahoo.com.

Conflict of interest: There is no conflict of interest to declare.

Received on May 27, 2021; Accepted on August 1, 2021. 